\title{
ATR-FTIR Spectroscopy Coupled with Chemical and Chemometric Analysis to Distinguish Between Some Sweet Wines
}

\begin{abstract}
CARMEN MIHAELA TO PALA*, LAVINIA DIANA TATARU
University of Pitesti, Department of Natural Sciences, Pitesti, 1 Tg. Vale Str., 110040, Pitesti, Romania

FTIR Spectroscopy correlated with some chemical characteristics and chemometric analysis have been applied to distinguish between sweet wines obtained from different Romanian varieties and Canadian icewine. Chemical analyses differentiate the two categories of origin in terms of sugar content, acidity and total polyphenol content but are expensive and time-consuming. Principal Component Analysis were performed using different regions of FT-MIR spectra for all wines. Principal Component Analysis of their chemical parameters indicated that the wines can be discriminated based on their different phenolic, carbohydrates, polyols content and geographical origin. FTIR spectroscopy coupled with chemometry is a profitable technique for distinguishing between different wines and validates the results obtained by chemical analysis.
\end{abstract}

Keywords: sweet wine; mid-infrared spectroscopy; principal component analysis, sugar content, icewine

Grape wine has a very complex composition (hydroxy compounds, carboxylic acids, nitrogenous compounds, aldehydes, vitamins, enzymes and many mineral substances) and a relatively low content of ethyl alcohol (less than $15 \%$ V/ V) so it is the healthiest alcoholic drink for the human body. The very complex chemical composition makes it impossible to classify wines according to rigorous scientific criteria. On the other hand, the chemical composition of a wine is unique not onlydue to its variety footprint, butalso to the geoclimatic conditions and winemaking technology. [1, 2].

Sweetness of a wine is determined by the level of residual sugar, remaining after fermentation stops, in balance with alcohol level, acidity and polyphenol content. According to EU regulation 753/2002 a wine containing more than $45 \mathrm{~g} / \mathrm{L}$ residual sugar is considered sweet $[3,4]$.

The technology of sweet wine production typically involves the dehydration of grape berries in order to increase the sugar concentration. This can be done in different ways. For example, in Tuscany, Italy, the grapes are dehydrated in specially places under shade and controlled temperatures, while in other Mediterranean countries (Cyprus, Greece, Spain, Turkey) are left to air dry, in open spaces. In France (Bordeaux) or Hungary (Tokay) the grapes are attacked by Botrytis cinereal [5].

In cold regions such as those in Canada, Germany, Austria or the United States, the high level of sugar in the famous icewines is getting by freezing the grapes or the grape juice. For these wines, the highly concentrated must is extracted from the frozen berries under pressure condition. The entire harvesting and pressing process must be carried out below $-8^{\circ} \mathrm{C}$. Juice will have anywhere from 32-46 Brix [6]. Icewine juice is concentrated in all soluble solids, including glucose and fructose, as well as acids and nitrogenous compounds. The management of fermentation biotechnology is very difficult and the fermentation lasts 2-6 months. How ever, these wines are included in top international level quality premium wines due to their sensory quality and longevity [7].

In Romania, sweet wines with a registered designation of origin (DOC) are obtained by delayed harvest, being classified as: DOC-CMD (full maturity harvest), DOC-CIB (berries ennoblement harvest) and DOC-CT (delayed harvest). Considering the amount of residual sugar, they can be: semi-sweet, with 12.1 - $50 \mathrm{~g} / \mathrm{L}$ of residual sugar; sweet, with more than $50 \mathrm{~g} / \mathrm{L}$ of residual sugar. These sweet wines are obtained in different vineyards, from some varieties such as Busuioaca, Muscat Ottonel, Tamaioasa Romaneasca, Grasa de Cotnari, sometimes Chardonnay and Pinot Gris, resulting wines for which sugar and acidity harmonize in the happiest way [8].

For the classification and characterization of sweet wines, numerous techniques and analytical methods can be used: the metallic content [9], volatile fraction [10, 11], aromatic profile [12].

Multivariate analysis has been suggested to differentiate or authenticate wines according to their geographical origin or grape variety using based on the compositional profiles [13].

Some fast, low cost and environmentally friendly methods to characterize the different categories of wine was developed by using FTIR-ATR spectroscopy combined with multivariate analysis [14] or mid-infrared (MIR), near-infrared (NIR), visible (VIS) and ultraviolet (UV) spectroscopy and chemometrics $[15,16]$.

This study aims to investigate some of the chemical characteristics and to distinguish between sweet wines obtained from different native and Canadian varieties by corelating results of chemical analyses (sugars, $\mathrm{pH}$, titratable acidity, total polyphenols and antiradical activity) with FTIR and chemometric analysis.

\section{Experimental part}

Wine samples

Eight samples of sweet commercial wine were analysed, five of which were certified in Romania (Cotnari and Mehedinti vineyard) and the other three were icewine produced in Canada.

Table 1 presents some characteristics of wine samples as: name (variety), origin, type of certification and way of obtaining (full maturity harvest-CMD, berries ennoblement harvest-CIB or delayed harvest-CT), year of production, organoleptic properties and ethanol content.

\section{Sugar content}

The sugar was determined by the refractometric method using a DigitaleHandrefraktometer DR201-95 which

* email: carmen.topala@gmail.com, Phone: 0745981621

REV.CHIM. (Bucharest) $70 \diamond$ No. $7 \bullet 2019$

http://www.revistadechimie.ro 
Table 1

THE SAMPLES OF WINE ANALYSED

\begin{tabular}{|l|l|l|l|l|l|}
\hline Sample & Name (Variety) & $\begin{array}{l}\text { Origin (Vineyard) and } \\
\text { Certification }\end{array}$ & Year & Organoleptic properties & $\begin{array}{l}\text { Alcohol } \\
(\% \text { V/V) }\end{array}$ \\
\hline 1 & Grasa de Cotnari (Cotnari 1) & $\begin{array}{l}\text { Cotnari } \\
\text { DOC-CIB }\end{array}$ & 2008 & white, sweet & 11.5 \\
\hline 2 & $\begin{array}{l}\text { Tamaioasa Romaneasca } \\
\text { (Tamaioasa 1) }\end{array}$ & $\begin{array}{l}\text { Vinju Mare Domains } \\
\text { DOC-CMD }\end{array}$ & 2016 & white, sweet & 13.5 \\
\hline 3 & $\begin{array}{l}\text { Cotnari Inedit- Busuioaca de } \\
\text { Bohotin } \\
\text { (Busuioaca) }\end{array}$ & $\begin{array}{l}\text { Cotnari } \\
\text { DOC-CMD }\end{array}$ & 2017 & rose, medium sweet & 11.5 \\
\hline 4 & $\begin{array}{l}\text { Grasa de Cotnari } \\
\text { (Cotnari 2) }\end{array}$ & $\begin{array}{l}\text { Cotnari } \\
\text { DOC-CMD }\end{array}$ & - & $\begin{array}{l}\text { old, white, medium } \\
\text { sweet }\end{array}$ & 11.5 \\
\hline 5 & $\begin{array}{l}\text { Tamaioasa Romaneasca } \\
\text { (Tamaioasa 2) }\end{array}$ & $\begin{array}{l}\text { Cotnari } \\
\text { DOC-CT }\end{array}$ & 2014 & white, sweet & 11.5 \\
\hline 6 & $\begin{array}{l}\text { Vidal Blanc } \\
\text { Aged in oak }\end{array}$ & $\begin{array}{l}\text { VQA Niagara Peninsula } \\
\text { Andrew Peller } \\
\text { Cabemet Franc }\end{array}$ & 2016 & $\begin{array}{l}\text { White, very sweet, very } \\
\text { intense and rich flavour }\end{array}$ & 11.0 \\
\cline { 5 - 6 } & Signature Series & 2016 & $\begin{array}{l}\text { Red, very sweet, very } \\
\text { intense and rich flavour }\end{array}$ & 11.5 \\
& Vidal & 2016 & $\begin{array}{l}\text { White, very sweet, very } \\
\text { intense and rich flavour }\end{array}$ & 11.0 \\
\hline
\end{tabular}

calculate the content in Brix degrees (\% sucrose, $\mathrm{m} / \mathrm{m}$ ) based on the index of refraction.

\section{Acidity}

The acids playa considerable role in wine quality. There are different organic acids in wines, and each of them contributes differently to total wine acidity or indirectly, to wine colour and stability [17].

Titrable acidity (TA) was determined by titration using a $0.1 \mathrm{~N} \mathrm{NaOH}$ solution (known correction factor), using phenolphthalein as a colour indicator. The results were converted and expressed in $\mathrm{g} / \mathrm{L}$ tartaric acid using the relationship:

$$
T A_{(\text {tartric acid, } g / l)}=0,075 \times \frac{V_{\mathrm{NaOH}} \times f_{\mathrm{NaOH}} \times C_{\mathrm{NaOH}}}{V_{\text {sample }}} \times 1000
$$

where: 0.075 is the amount of tartaric acid corresponding to 1 meq H $\mathrm{H}^{+} / \mathrm{L}, \mathrm{V}_{\mathrm{NaOH}}$ is the volume of $\mathrm{NaOH}$ solution with the concentration $\mathrm{C}_{\mathrm{NaOH}}$ and correction factor $\mathrm{f}_{\mathrm{NaOH}}$ used in the titration and $\mathrm{V}_{\text {sample }}$ is the volume of sample taken in the analysis.

Actual acidity or real acidity expressed by $\mathrm{pH}$ was measured using an InoLab $730 \mathrm{pH}$-meter

\section{Total polyphenols content}

The total polyphenols content (TPC) was determined by the Folin-Ciocalteu method, that involved the reduction of the $\mathrm{F}-\mathrm{C}$ reagent by the phenolic compounds in wine with the formation of a blue complex which has a maximum of absorption at $760 \mathrm{~nm}$. The absorbance was interpolated and expressed in gallic acid on a calibration curve obtained with a series of $12.5-150 \mu \mathrm{g} / \mathrm{mL}$ galic acid solution and describe by a linear regression equation. The results were obtained as an average of three consecutive determinations and read at a UV-Vis J asco 730 spectrometer.

By multiplying the absorption values by 20 , in the case of white wines, and by $20 x$ dilution factor, for the red ones, we have the total polyphenols index (TPI) that allows to classify the wines in: supple taste wines (TPI < 30), wellformed wines $(30<\mathrm{TPI}<50)$ and astringent, with excess of polyphenols wines (TPI > 50) [8].

\section{Antiradical power}

The evaluation of the antiradical power of the wine was made in comparison with 2,2-Diphenyl-picrylhydrazyl (DPPH), one of the most stable free radical organic compounds. It accepts $\mathrm{H}$. from the antioxidants present in the sample and the antioxidant effect is proportional to the disappearance of the DPPH radical. DPPH has a strong peak absorption at $517 \mathrm{~nm}$ (violet). The colour changes to yellow due to DPPH H. formation. The antioxidant effect can be evaluated by decreasing absorbance at $517 \mathrm{~nm}$ [18].

The DPPH ( $394.32 \mathrm{gram} / \mathrm{mol}$ ) methanolic solution with a concentration of $6 \times 10^{-5} \mathrm{~mol} / \mathrm{L}\left(2366 \times 10^{-5} \mathrm{~g} / \mathrm{L}\right)$ in methanol was obtained and then, the reference solution was prepared by diluting $3900 \mu \mathrm{L}$ with $100 \mathrm{~mL}$ methanol. Radical reaction was initiated by transferring to $25 \mathrm{~mL}$ of each wine sample $3975 \mu \mathrm{L}$ of reference solution (dilution ratio 1: 160). For each sample, the absorbance value was measured after 15 min of incubation in the dark and at the room temperature, at 517nm, on a UV-Vis Jasco 730 spectrometer.

Percent inhibition of DPPH. (I\%) was calculated from the decrease in absorbance with the relation:

$$
I \%=\frac{A_{\text {blank }}-A_{\text {sample }}}{A_{\text {blank }}} \times 100
$$

where: $A_{\text {bank }}$ is the absorbance for the blank (reference solution of ethanol-DPPH ethanolic solution) and $A_{\text {sample }}$ is the absorbance for the sample mixed with DPPH reference solution.

\section{The ATR-FTIR spectral analysis}

The ATR-FTIR spectra were recorder in a range between 4000-400 $\mathrm{cm}^{-1}$ using a FTIR J asco 6300 spectrometer, detector TGS, apodization Cosine. An ATR accessory equipped with a diamond crystal (Pike Technologies) was used for sampling. Each sample $(10 \mu \mathrm{L})$ was spread uniformly through on the surface of the diamond ATR crystal using a micropipette.

At the same time, the viscous residues were also obtained after $1 \mathrm{~mL}$ of each sample was dropped on a pan and volatilized for $8 \mathrm{~h}$. For each viscous and liquid wine samples the IR spectra were recorded and analysed for classification.

The spectral data were processed with JASCO Spectra Manager II software. Liquid samples of wine, without any preparation, were scanned at $4 \mathrm{~cm}^{-1}$ resolution, accumulation: 100 scans. For each subsample, three replicate spectra were recorded to ensure the spectral reproducibility and assess analytical precision and the average spectrum was done. Background reference 
spectra were recording using air after every sample to minimize the interference due to carbon dioxide and water vapor in the atmosphere. Between measurements, the ATR crystal was carefully cleaned using acetone then dried with a soft tissue.

\section{Data Analysis}

Infrared Spectra were exported from Spectra Manager, in ASCII (dx) format, into the Unscrambler Software (Edition X 10.3, Camo. Oslo Norway) for chemometric analysis. Spectra were pre-processed using the secondderivative transformation, the Savitzky-Golayderivation. The use of spectra derivatives with Savitzky-Golay algorithm as a chemometric pre-processing technique is widely reported in most classification based on FTIR spectroscopy [12-14, 19-21]. The principal component analysis (PCA) model was developed using cross validation. PCA was performed both on the entire spectral range (4000 to 400 $\mathrm{cm}^{-1}$ ), and on the MIR 'fingerprint' (i.e. 1800 to $700 \mathrm{~cm}^{-1}$ ), on the peak areas corresponding to regions $940-600 \mathrm{~cm}^{-1}$ (1), $1000-1120 \mathrm{~cm}^{-1}$ (2) and $3000-2800 \mathrm{~cm}^{-1}$ (3).

\section{Results and discusions}

Table 2 comprise the values obtained for the chemical parameters investigated for the eight wine samples.

Analysing the sugar content, Icewine samples are found to have the highest values (27-29\% Brix), practically double quantities than the ones contained in local wines (10-14 $\%$ Brix). These values are positively correlate with the titratable acidity (TA) expressed in tartric acid equivalents. For this parameter higher values also characterize the Canadian wine. A minimum value ( $4,53 \mathrm{~g}$ tartric acid eq /l) is obtained for sample 2, Tamaioasa Romaneasca from Vinju Mare Domains which is the wine with the highest alcohol content (13.5\%).

There is no proportionality between titratable acidity and the $\mathrm{pH}$ values indicating the degree of ionization of acids and acid salts of wine. Concentration of free hydrogen ions is higher for all the autochthonous varieties (sample 1-5).

Polyphenols content are also important among the chemical compounds present in wine not only because of their influence on colour and taste but also due to their antioxidant activity and benefices on human health $[22,23]$. These molecules confirmed to possess a freeradical scavenging activity, so that the total polyphenols content can be correlated with the antiradical power evaluated by the DPPH assays. Recent studies have shown that polyphenols are active in inhibiting radicals, while sugars are effective in inhibiting assays mediated by hydroxyl radical formation. Sugars display antioxidant capacities that cannotbe underestimated, and their action can involve polyphenols especially in samples with more than $500 \mathrm{~g} / \mathrm{L}$ sugar concentration [24].

In the analysed samples, the Cabernet Franc icewine variety stands out with a much higher content of polyphenols and the highest DPP inhibition power. This variety, a well-formed wine (TPI > 30), with a brilliant ruby hue, is considered very rare and precious and is specific to the Ontario-Canada area. For the other samples, the values are comparable and place the wines in the category of supple to taste (TPI < 30).

\section{FT-MIR spectral fingerprinting of wine samples}

The ATR-MIR spectra of commercial wines showed moderate to strong absorbance peaks at 1044, 1085, 16361638 and around at $3270 \mathrm{~cm}^{-1}$ (fig. 1) with peaks at 3270 and 1636-1638 $\mathrm{cm}^{-1}$ corresponding to the $\mathrm{O}-\mathrm{H}$ stretching and bending respectively, associated with water $[25,26]$.

In all samples, similar spectral features were generally obtained. Figure 1 exhibits the general FT-MIR spectra of all wine residue samples.

In order, to get an overview of the compositional differences that occurred in these eight samples of wine an overlapping image of the of Romanian and Canadian wine samples was taken and it is presented in figure 2 . Various spectral bands occur in the region from 1800-700 $\mathrm{cm}^{-1}$, which is part of the fingerprint region, such as those corresponding to the vibration of the $\mathrm{C}-\mathrm{O}, \mathrm{C}-\mathrm{C}, \mathrm{C}-\mathrm{H}$ and $\mathrm{C}-\mathrm{N}$ bonds. It was possible to consider a few specific regions which can be useful for wines' characterization [27-29]. Region 1 (690-940) is responsible for phenols, region 2 (1000-1120 $\mathrm{cm}^{-1}$ ) is responsible to carbohydrates (glucose, fructose and oligosaccharides), and region 3 (2800-3000 $\mathrm{cm}^{-1}$ ) for polyols (mainly glycerol).

Table 3 includes the FT-MIR absorption wave numbers, specific to the 3 regions of each wine fingerprinting.

All spectra were characterized by a similar profile. No visual differences were observed between the MIR spectra of wine samples analysed. It was observed that water and ethanol absorption peaks dominate the spectrum. Chemometric analysis allow the differentiation of wines.

The chemometric analysis. Principal Component Analysis (PCA)

The Principal Component Analysis (PCA) is a wellestablished analysis technique which works by finding the correlation between a set of variables and then creating a new set of uncorrelated variables named principal components (PCS). PCA was performed on the MIR spectra to examine qualitative differences within the set of sw eet wines related to the two production systems $[14,29,30]$.

Figures 3-6 present the results of PCA analysis and scores. PCA was carried out between the domain of the selected spectral region $1800-700 \mathrm{~cm}^{-1}$ for wine (discriminate sweet wine types: Romanian and Canadianfig. 3). The first three principal components (PCs) represent $97 \%$ of the total variance $(\mathrm{PCl}=72 \%, \mathrm{PC2}=22 \% ;=3 \%$ and $\mathrm{PC} 3=3 \%)$. This indicates that these three components were sufficient to provide a clear separation

\begin{tabular}{|c|c|c|c|c|c|c|}
\hline \multirow[t]{2}{*}{ Sample } & \multirow{2}{*}{$\begin{array}{l}\text { Sugar } \\
\% \text { BRIX }\end{array}$} & \multicolumn{2}{|c|}{ Acidity } & \multicolumn{2}{|l|}{ Total polyphenols } & \multirow{2}{*}{$\begin{array}{l}\text { I\% } \\
\text { DPPH } \\
\text { inhibition }\end{array}$} \\
\hline & & $\mathrm{pH}$ & $\begin{array}{l}\text { Titrable acidity (TA) } \\
\mathrm{g} \text { tartric acid } / 1\end{array}$ & $\begin{array}{l}\text { Total polyphenols content } \\
\text { (TPA) } \\
\mu \mathrm{g} \text { galic acid } / \mathrm{ml}\end{array}$ & TPI & \\
\hline 1 & 13.6 & 2.99 & 4.84 & $46.0455 \pm 0.0283$ & 13.53 & 68.42 \\
\hline 2 & 12.0 & 2.88 & 4.53 & $33.1692 \pm 0.0405$ & 10.08 & 52.58 \\
\hline 3 & 10.6 & 2.83 & 5.36 & $51.2353 \pm 0.0533$ & 14.92 & 76.94 \\
\hline 4 & 11.1 & 2.86 & 5.51 & $40.0088 \pm 0.0695$ & 11.91 & 56.44 \\
\hline 5 & 13.8 & 2.76 & 5.74 & $55.2947 \pm 0.0508$ & 16.01 & 60.47 \\
\hline 6 & 29.0 & 3.44 & 7.12 & $61.5184 \pm 0.0363$ & 17.68 & 54.45 \\
\hline 7 & 28.1 & 3.62 & 7.35 & $125.0095=0.0510$ & 33.68 & 82.51 \\
\hline 8 & 27.7 & 3.59 & 6.90 & $57.2224 \pm 0.0156$ & 16.53 & 51.83 \\
\hline
\end{tabular}



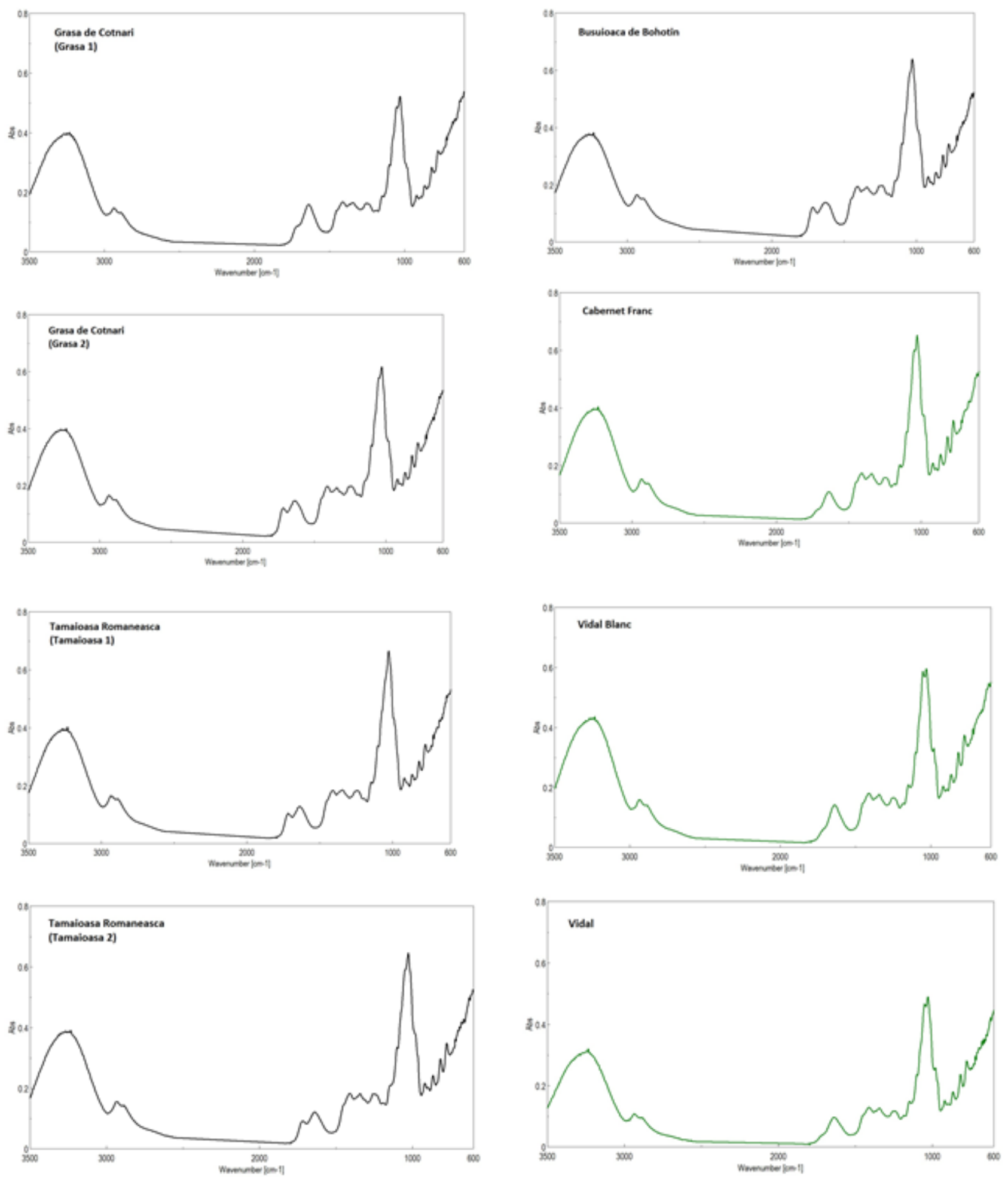

Fig. 1. ATR-MIR spectra registered for all 8 sweet wine samples, in the region $600-3500 \mathrm{~cm}^{-1}$

between the groups. The Romanian wine varieties are located on the right of the plot, while Canadian sweet wines are located on the left of the graph.

Figure 4 represents the scores for the region 600-940 $\mathrm{cm}^{-1}$, specific to for phenolic compounds (chemical compounds that affect the taste, color and mouthfeel of wine). In this case, the first principal component (PC1) explained $74 \%$ of the variability, the second principal component (PC2) explained $23 \%$ and the third principal component (PC3) with $2 \%$ of the variability, together explaining $99 \%$ of the whole variability of wine samples and suggesting a good clustering based on acidity. The type of wine separates: in the rightare the Romanian wines (Grasa de Cotnari - Grasa 1, Tamaioasa Romaneasca Vanju
Mare - Tamaioasa 1, Busuioaca de Bohotin - Busuioaca, Grasa de Cotnari - Grasa 2 and Tamaioasa Romaneasca Cotnari- Tamaioasa - 2) and in the left part of diagram are Canadian wines (Vidal Blanc Aged in Oak, CabernetFrans and Vidal). Moreover Grasa de Cotnari 1 and 2 are in the lower part of the right of plot and Tamaioasa 1 and 2 and Busuioaca are in the positive quadrates of both $\mathrm{PCl}$ and PC2. Cabernet Franc wine is separated from the other canadian wines. These are in concordance with total polyphenols values obtained by the Folin-Ciocalteu method (table 1).

Figure 5 which represents the scores for the region 1000 $1120 \mathrm{~cm}^{-1}$, specific to carbohydrates derivatives, revealed a good clustering of wines based on sweetness index. The 

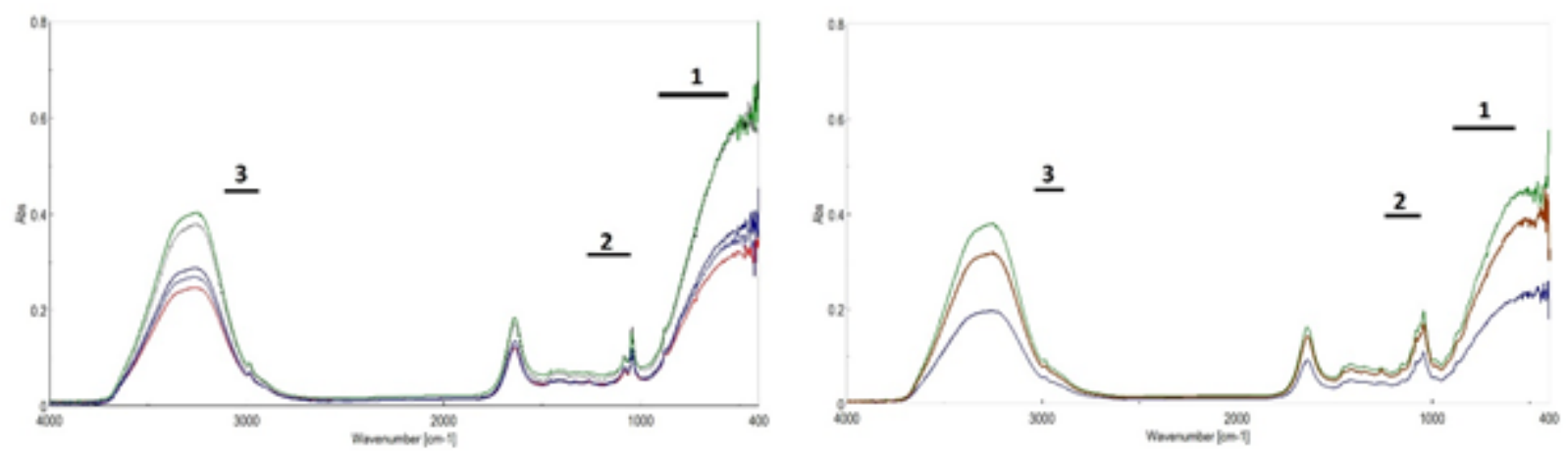

Fig. 2. Overlapped ATR-MIR spectra for the five sweet Romanian commercial wine samples (left) and three Canadian Icewine (right)

Table 3

ATR-MIR WAVE NUMBERS SPECIFIC TO THE REGIONS OF EACH WINE FINGERPRINTING

\begin{tabular}{|c|c|c|c|}
\hline Sample of wine & $1\left(600-940 \mathrm{~cm}^{-1}\right)$ & $1\left(1000-1200 \mathrm{~cm}^{-1}\right)$ & $3\left(2800-3000 \mathrm{~cm}^{-1}\right)$ \\
\hline $\begin{array}{l}\text { Grasa de Cotnari (Grasa } \\
\text { 1) }\end{array}$ & $\begin{array}{l}677,719,775,817, \\
864,918\end{array}$ & 1029,1096 & 2888,2936 \\
\hline $\begin{array}{l}\text { Tamaioasa Romaneasca } \\
\text { (Tamaioasa 1) }\end{array}$ & $\begin{array}{l}675,689,719,732, \\
774,816,864,917\end{array}$ & 1025,1099 & 2888,2935 \\
\hline $\begin{array}{l}\text { Cotnari Inedit- } \\
\text { Busuioaca de Bohotin } \\
\text { (Busuioaca) }\end{array}$ & $\begin{array}{l}668,677,719,776, \\
816,863,899.916\end{array}$ & 1027,1099 & 2887,2934 \\
\hline $\begin{array}{ll}\text { Grasa de } & \text { Cotnari } \\
\text { demidulce } & \\
\text { (Grasa 2) } & \end{array}$ & $\begin{array}{l}669,719,775,816, \\
862,900,917\end{array}$ & 1028,1100 & 2886,2934 \\
\hline $\begin{array}{l}\text { Tamaioasa Romaneasca } \\
\text { (Tamaioasa 2) }\end{array}$ & $\begin{array}{l}664,677,691,719, \\
775,816,864,901, \\
918\end{array}$ & 1026,1100 & 2883,2934 \\
\hline $\begin{array}{l}\text { Vidal Blanc } \\
\text { Aged in oak }\end{array}$ & $\begin{array}{l}642,659,719,776, \\
816,862,891,916\end{array}$ & $1029,1051,1100$ & 2888,2935 \\
\hline Cabemet Franc & $\begin{array}{l}612,624,659,719, \\
776,816,864,917\end{array}$ & $1027,1046,1100$ & 2889,2935 \\
\hline Vidal & $\begin{array}{l}620,647,666,697, \\
719,729,749,776, \\
816,864,917\end{array}$ & $1028,1050,1101$ & 2884,2937 \\
\hline
\end{tabular}
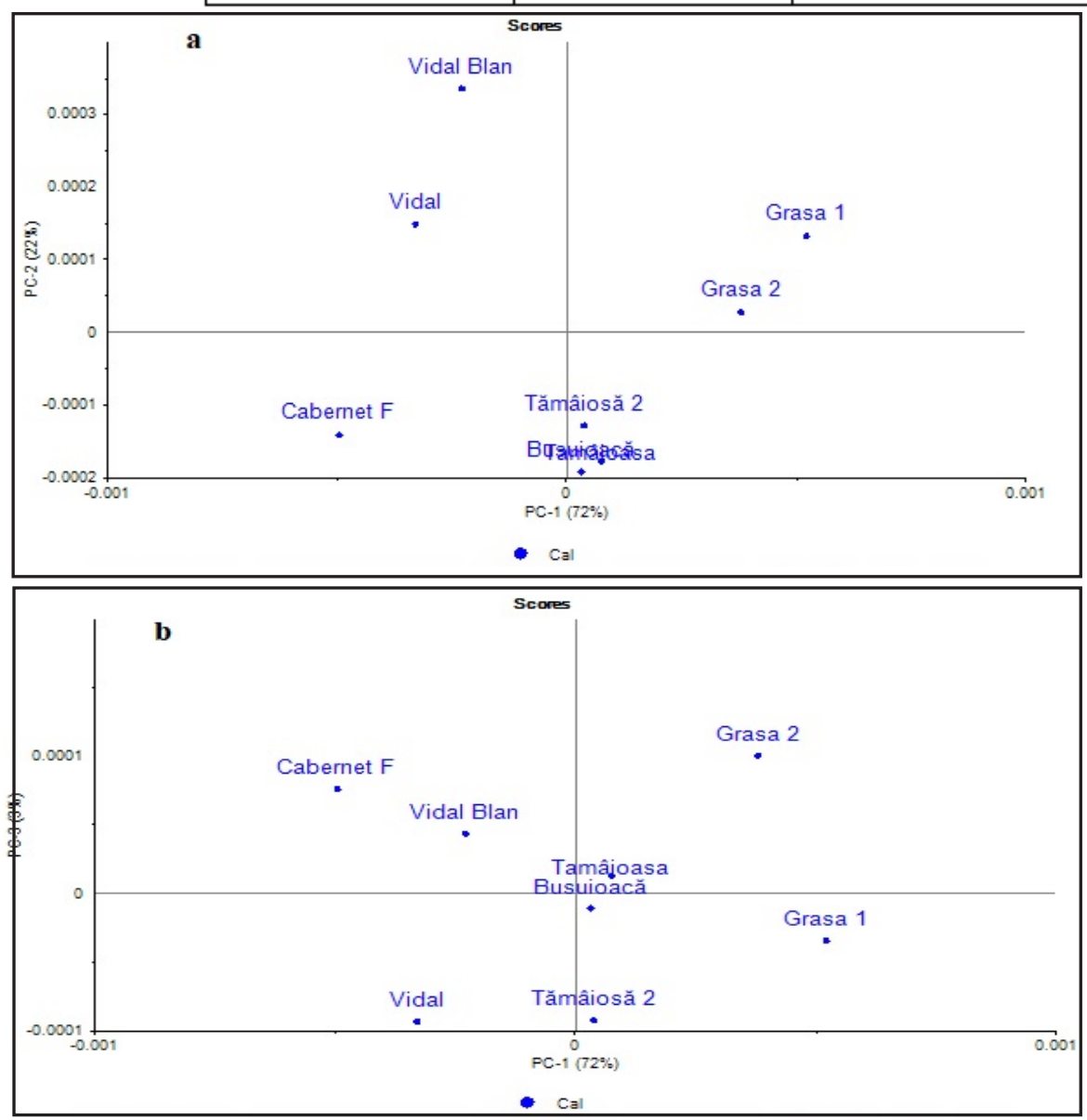

Fig. 3. 2-D scores obtained from PCA of FTIR spectra for the first two PCs based on the FTIR fingerprint region (700-1800 $\left.\mathrm{cm}^{-1}\right)$ a), and PC3 versus PC1 b) 

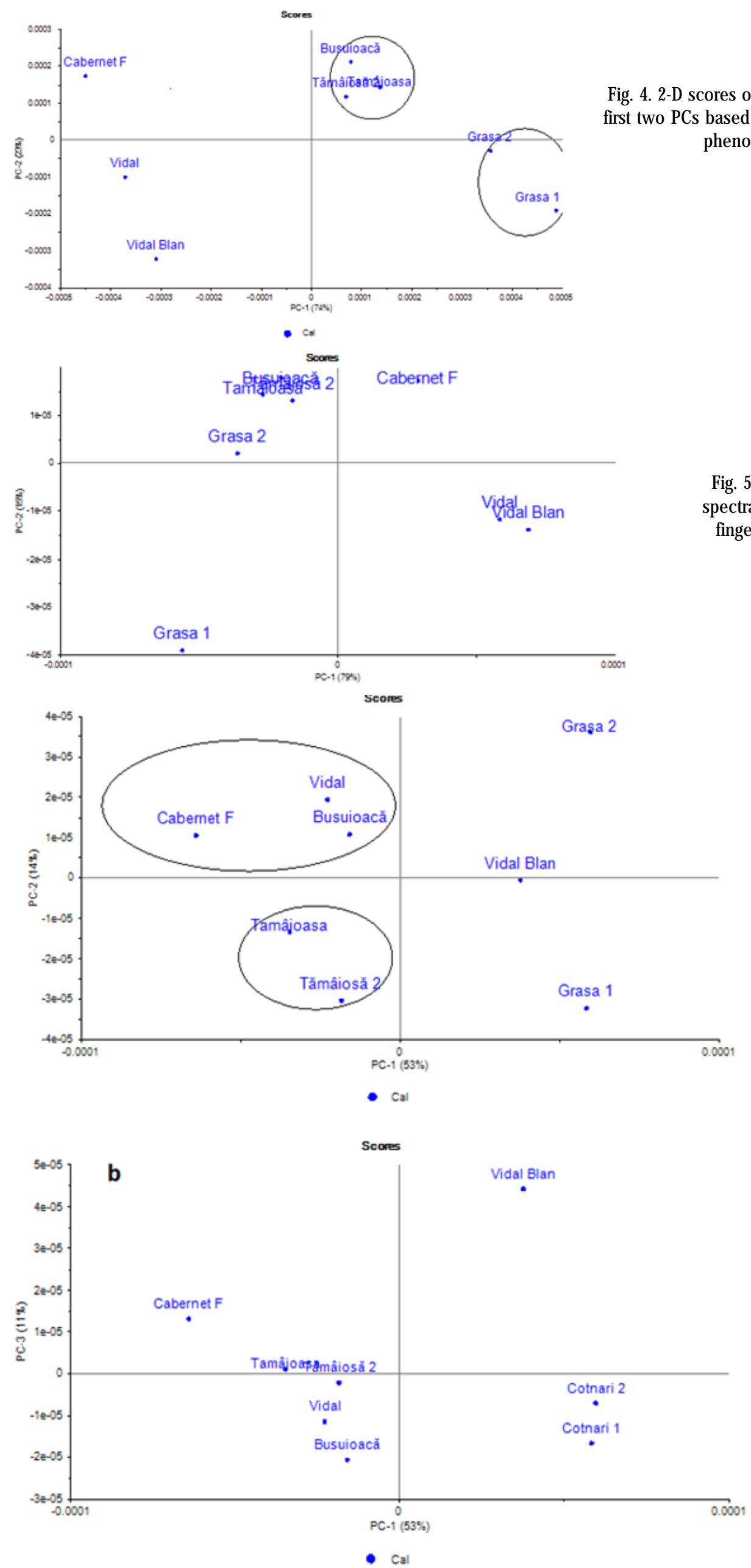

Fig. 4. 2-D scores obtained from PCA of FTIR spectra for the first two PCs based on the FTIR fingerprint region specific to phenolic derivatives $\left(600-940 \mathrm{~cm}^{-1}\right)$

Fig. 5. 2-D scores obtained from PCA of FTIR spectra for the first two PCs based on the FTIR fingerprint region specific to carbohydrates $\left(1000-1120 \mathrm{~cm}^{-1}\right)$
Fig. 6. 2-D scores obtained from PCA of FTIR spectra for the first two PCs based on the FTIR fingerprint region specific to polyols $\left(2800-3000 \mathrm{~cm}^{-1}\right)$ a), and PC3 versus $\mathrm{PC} 1 \mathrm{~b}$ ) 
first PC explains $79 \%$ while the second and the third principle component 2 and $2 \%$ respectively of the total variance. The type of wine separates: in the right of the diagram are the Canadian sweet wines. These are in concordance with sugar content values presented in table 1.

Figure 6 represents the scores for the region 2800-3000 $\mathrm{cm}^{-1}$, specific to polyols (mainly glycerol). The first PC explains 53\% while the second and the third principle component $14 \%$ and $11 \%$ respectively of the total variance. Vidal Blanc Aged in oak is separated from the rest two Canadian wines. This result may be due to processes that occur during wine aging, such as: the release of some compounds from the oak wood into the wine; chemical reactions involving both wine and wood compounds as well as oxygen permeation through the wood; evaporation of volatile compounds with the concentration of non-volatile ones [31, 32]

Polyols especially glycerol afford fullness to wine and decrease the perception of acidity, particularly in dry white wines. Also glycerol significantly contributes to the complexity of wine and the length of the finish. Its contribution to sw eetness was considered significant, but only when present at high concentrations [33].

\section{Conclusions}

This study demonstrated the capacity for ATR-MIR spectroscopy (combined with multivariate analysis) to broadly classify wines. The results demonstrated qualitative compositional differences between sweet Romanian and Canadian wine, that can be observed by MIR spectroscopy and used to distinguish wines, following PCA.

The chemometric instruments are rapid and allow an accurate separation of the wine by the sugar content, phenols, polyols, with very good results from the spectrum of a drop of wine in the absence of the chemical analysis of the sample necessary for these determinations.

The chemical analyzes show that the Romanian sweet wines and Canadian icewines are distinguished by the sugar content, acidity and the total content of polyphenols. The differences are particularly remarkable in terms of sugar content where the values are double in icewines versus the Romanian ones. All wines demonstrate antiradical activity without major differences betw een the two groups of origin. How ever, chemical analyzes are laborious, time consuming and expensive. In contrast, ATRMIR spectroscopy combined with multivariate analysis proved to be a quick and effective technique to distinguish between different samples of sweet wine.

The separation of wines by chemometry according to the content of carbohydrates, phenols, polyols is in good concordance with that obtained by chemical methods

\section{References}

1. CHIRA, K., TEISSEDRE, P.L., Eur Food Res Technol, 240, 2015, p.533.

2. SONG, C.Z., LIU, M.I., MENG, J.F., SHI, P.B., ZHANG, Z.W., XI, Z.M., Eur Food Res Technol, 242, 2016, p.609.

3. ***COMMISSION REGULATION (EC) No 753/2002 of 29 April 2002, Official J ournal of the European Communities, 20094.5.2002.

4. ***COMMISSION REGULATION (EC) No 2016/2006 of 19 December 2006, Official J ournal of the European Union, 29.12.2006, L 384/38.
5. TOSI, E., AZZOLINI, M., LORENZINI, M., TORRIANI, S., FEDRIZZI, B., FINATO, F., CIPRIANI, M., ZAPPAROLI, G., Eur Food Res Technol, 236, 2013, p. 853.

6. PIGEAU, G.M., BOZZA, E., KAISER, K., INGLIS, D.L., J ournal of Applied Microbiology, 2007, 103, p.1691.

7. JING, W., MIN, L., JIXIN L., TENGZHEN, M., SHUNYU, H., MORATA, A., SUAREZ-LEPE, J .A., Biotechnology of Ice Wine Production in: Advances in Biotechnology for Food Industry-Handbook of Food Bioengineering, 2018, p. 267.

8. TARDEA, C., SARBU, G., TARDEA, A., Clasificarea vinurilor in: Tratat de vinificatie, Ed. Ion Ionescu de la Brad, 2000, p.171.

9. FRÍAS, S., PEREZ TRUJ ILLO, J.P., PENA, E.M., CONDE, J.E., Eur Food Res Technol, 213, 2001, p.145.

10. MÁRQUEZ, R., CASTRO, R., NATERA R., GARCIA-BARROSO, C., Eur Food Res Technol, 226, 2008, p.147.

11. YOO, K.S., KIM, J.E., MOON, J.S., JUNG, J.Y., KIM, J.S., YOON, H.S., CHOI, H.S., KIM, M.D., SHIN, C.S. and HAN, N.S., Food Sci. Biotechnol., 19(1), 2010, p. 43.

12. LORENZO, C., PARDO, F., ZALACAIN, A., ALONSO, G.L., SALINAS, M.R., Eur Food Res Technol., 227, 2008, p.777.

13. SOLEAS, G.J ., DAM, J., CAREY, M., GOLDBERG, D.M., Journal of Agricultural and Food Chemistry, 45(10), 1997, p. 3871.

14. COZZOLINO, D., CYNKAR, W., SHAH, N., SMITH, P., Anal Bioanal Chem., 401, 2011, p.1475.

15. CONDURSO, C., CINCOTTA, F., TRIPODI, G., VERZERA, A., Eur Food Res Technol., 244, 2018, p.1073.

16. MARTELO-VIDAL, M.J., VÁZQUEZ, M., Czech J. Food Sci., Vol. 32(1), 2014, p.37.

17. CHIDI, B.S., ROSSOUW, D., BUICA, A.S., BAUER, F.F., S. Afr. J. Enol. Vitic., 36(3), 2015, p.316.

18. BRAND-WILLIAMS, W., CUVELIER, M. E., BERSET, C., LebensmWiss.Technol., 28,1995, p. 25.

19. CHATFIELD, C., COLINS, A.J ., Introduction to Multivariate Analysis, Chapman \&Hall, London, 1980.

20. JOLLIFFE, I.T., Principal Component Analysis, Springer-Verlag, New York, 1st Ed., 1986.

21. PUI, A., TANASE, C., COZMA, D.G., BALAES, T., Environmental Engineering and Management J ournal, 12, 2013, 3, p. 527.

22. HOLSER, R.A., ISRN Spectroscopy, vol.2012, Article ID 493203, 2012, p.1.

23. MORENO, L.C., RUDNER, P.C., GARCIA, J.M.C., PAVÓN, J.M.C., Microchim. Acta, 148, 2004, p.93.

24. PEINADO, J., LOPEZ DE LERMA, N., PEINADO, R.A., Eur Food Res Technol., 231, 2010, p.363.

25. HASHIMOTO, A., KAMEOKA, T., Appl. Spectrosc., 54, 2000, p.1005. 26. PATZ, C.D., BLIEKE, A., RISTOW, R., DIETRICH, H., Anal. Chim. Acta, 513, 2004, p. 81.

27. BANC, R., LOGHIN, F., MIERE, D., FETEA, F., SOCACIU, C., Not Bot Horti Agrobo, 42(2), 2014, p.556.

28. TODASCA, M.C., FOTESCU, L., HINCU, F.A., HANGANU, A., CHIRA, N.A., ROSCA, S., Rev. Chim. (Bucharest), 61, no. 11, 2010, p. 1043.

29. TOPALA, C.M., TATARU, L.D., Rev. Chim. (Bucharest), 69, no. 2, 2018, p. 470.

30. RIOVANTO, R., CYNKAR, W.U., BERZAGHI, P., COZZOLINO, D., J. Agric. Food Chem., 59, 2011, p.10356.

31. DE ROSSO, M., PANIGHEL, A., DALLA VEDOVA, A., STELLA, L., FLAMINI. R., J Agric Food Chem., 2009 ;57(5), p.1915.

32. CANAS, S., Beverages, 2017, 3, p. 55.

33. RIBEREAU-GAYON, J., GLORIEs, Y., MAUJEAN, A., DUBOURDIEU, D., Handbook of Enology. The Microbiology of Wine and Vinifications, 1998, Vol. II. (1st ed). John Wiley and Sons, Ltd., New York.

Manuscript received: 13.01 .2019 